International Journal of English Literature and Social Sciences
Vol-6, Issue-5; Sep-Oct, 2021

Peer-Reviewed Journal

\title{
Factors Affecting Performance of Female Employment in Uttar Pradesh
}

\author{
Dr. Arvind Kumar
}

Assistant Professor, Department of Economics, Monad University, Hapur, Uttar Pradesh, India

Received: 10 Sep 2021; Received in revised form: 30 Sep 2021; Accepted: 08 Oct 2021; Available online: 16 Oct 2021

(C)2021 The Author(s). Published by Infogain Publication. This is an open access article under the CC BY license

(https://creativecommons.org/licenses/by/4.0/).

\begin{abstract}
Female is nearly half of the world's population having mammoth potential however being under-utilized for the economic development of the nation. The main objective of the paper is to analysis the socio-economic factors affecting the female employment in the unorganized sector with special reference to Uttar Pradesh. There are many socio-economic factors that affect female employment such asmarital status, family backgrounds, education, thinking of neighbor and relative etc. These factors affect in both way direct and indirect ways. Primary data is taken in this research paper to analysis the comparative study between Meerut district and Unnao district in Uttar Pradesh. The data is analysis through descriptive statistics to find out the authentic result.
\end{abstract}

Keywords - Female employment, Marital status, Education, Family responsibility.

\section{INTRODUCTION}

Female are nearly half of the world's populations having mammoth potential however being under-utilized for the economic development of the nation. Approximately half of the Indian population constitutes female and half of them are literate. Female's work participation Rate (FWPR) is about one- third. Majority of female are involved in the unorganized sector and domestic sector. Female's participation rate in the unorganized sector play very significant role in the economy. In the unorganized sector workers involves near about 90 per cent where 87 per cent stands for males and 97 per cent for females (NSS Report No. 557).

Women in our society have so far had only a secondary status and the economic dependence of women upon men is one of the primary reasons which has pushed them into the background and resulted into their secondary status both within and outside the family (Wadhera 1976). In spite of the fact that the women have proved their mettle in every walk of life, their contribution is not given due credit in most cases. In India women constitute nearly half of the total population and they play a vital role in domestic sphere, in the rural field and also in urban economy. Yet, their economic status is still low as it reflects from the census data, particularly of those who are engaged in the informal sector of urban economy (Tripathy and Das 1991). It is found that among all categories in the informal sector, domestic servants' income is the lowest and the problems are many (Sundaram 1996). They are engaged in household tasks, which include washing utensils, floor cleaning, washing of clothes, cooking as well as some outdoor tasks such as purchase of vegetables etc. Most of them live in slums; lead a monotonous life without any colour, struggle everyday for their survival and face numerous problems in day to- day life like long hours of work, insecurity of job, low status at home and outside (Gathia 1983). Women workers contribute significantly to national development by performing remunerated/paid and unremunerated/unpaid work. They also struggle to combine their roles to look after their families. In many- a -case, they are at disadvantage as their workplace 33 is in people's private homes, outside the arena of labour inspectors. Women household workers have a double burden as there is greater demand for their skills as care-givers and service workers outside home but 
they also work inside home doing the same work which is unpaid.

The social development is a process of transformation of social studies households' members of a section of society. It highlights that the change in the social status of the society, social participation, social equality, social justice and social emancipation in the state of Uttar Pradesh. The economic development reveals that the economic development in term of production, income, employment, wages, savings, education and consumption are important of respondents. The result of the field survey are presented here a systematically on issue base like social development and economic development of small and marginal farmers who are involved to take agricultural credit last year continuously in Uttar Pradesh. With this background, this paper focuses on gender wise status of education and different social and economic factors influencing female employment in the districts of Meerut and Unnao with the help of primary date.

\section{Factors Affecting Female Employment}

In every circumstance, in every set of key of development and socio-economic status, female have faced worse than men in all area and in all level of population. The factors influence of female labour force participation depends on several factors which may separate from one category to another. These factors respond to economic, social, cultural, demographic and psychology. These classifications of factor play important role in every life of female. In every society, female has a vital role to develop the nation. She always plays a specific and crucial role, whether visible or not. In our society, women act as mother, wife, and sister and perform very important role. She always depends upon male for survival in their society. There is a very clear difference between male and female entitlement such as, in work, employment, earnings, education, health status and decision-making powers. Female average earning is time after time or constantly very lower than those of male.

\section{Households Income}

Household income play very important role in getting employment. Household income influences female's decision of working or not to enter the labour force. Household's income consists of income of husband, income of family members. Neoclassical economics recommended that labour market involvement depends seriously on the degree of supply and demand of workers in the economy.

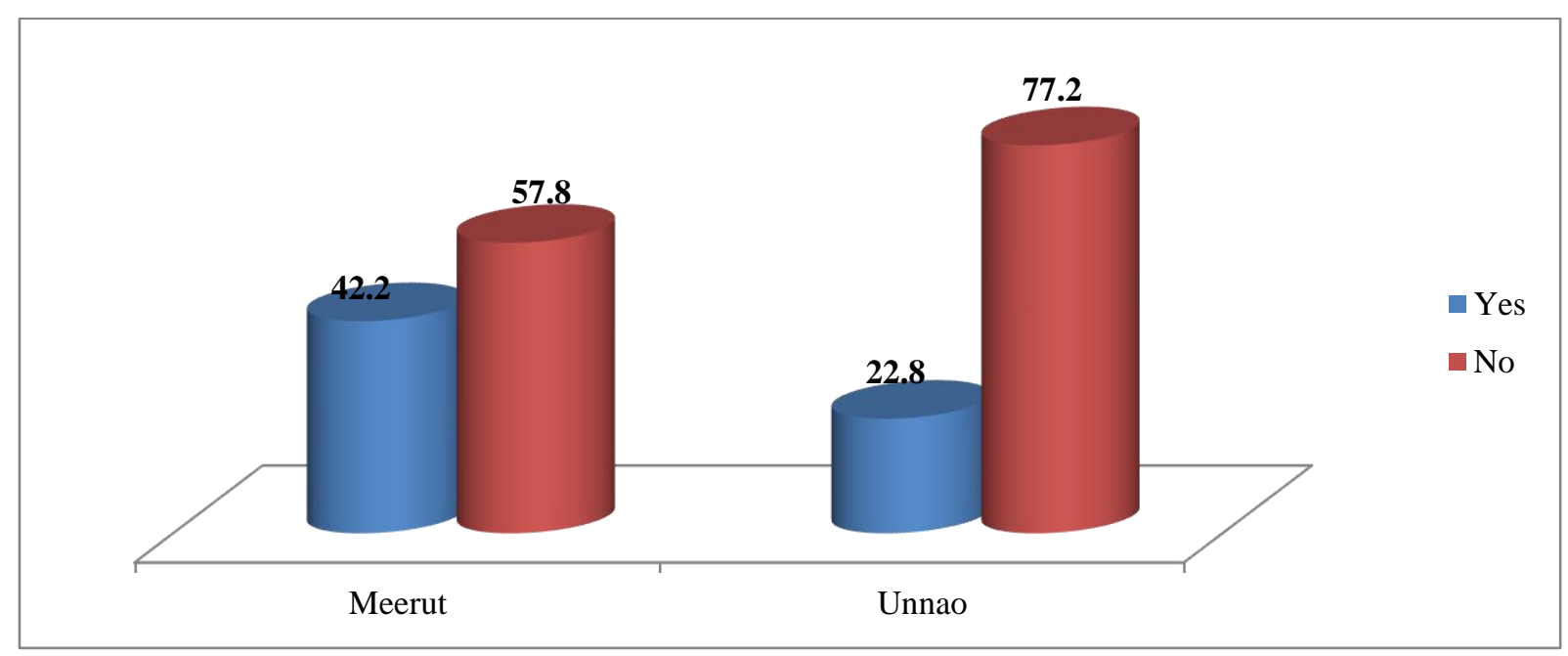

Fig.1: Percentage of household's income for livelihood is sufficient or not

Source- Estimated Field Survey

Figure 1 gives the detail of Unnao district, only 22.8 per cent household's income is enough for family but 77.2 per cent income is not sufficient. Hence, female of Unnao district want to more work to do but work is not sufficient according to their family requirement. So, the condition of Unnao district is not good in case of female employment.

IJELS-2021, 6(5), (ISSN: 2456-7620)

https://dx.doi.org/10.22161/ijels.65.29

\section{Family responsibility}

Working female has to bear the double burden of work not only at home but also outside. They have to wake up earlier than rest of the members of the family especial male member. They did all kinds of household activities like washing, cooking, cleaning, taking care of the livestock taking care of the elderly and the children, and socializing with neighbors and relatives. 
Table 1: Percentage of female responsibility in the Family

\begin{tabular}{|c|c|c|c|}
\hline District & Children care & Domestic duties & Caring of old age \\
\hline Meerut & $(39.40)$ & $(42.80)$ & $(17.80)$ \\
\hline Unnao & $(32.20)$ & $(45.60)$ & $(20.00)$ \\
\hline Total & $(35.80)$ & $(44.20)$ & \\
\hline
\end{tabular}

Source- Estimated Field Survey

Female are almost half of the world's populations having enormous potential but being under-utilized or unutilized for the economic development of the nation. In case of Unnao, this percentage is 32.20 . While in case of domestic duty such as- washing cloth, clean utensil, taking broom, clean the floor etc. 42.80 per cent stand for female in district Meerut and on the other side 45.60 per cent stand for district Unnao (Table 1). Female of Meerut teach more to their children as compared to Unnao. This is due to quality and awareness of education. Females faced many difficulties due to domestic responsibilities. Females faced many problems and one of them is dual role in the family.

\begin{abstract}
Marital Status
Marriage is a legal union of persons of opposite sex established by civil, religious or other means of recognised law or social customs (NSS, 2001). Marriage is an institution and compulsory phenomena for society. Percentage of females who work before marriage is high in Meerut rather than Unnao because of more opportunities to work. Marital statuses are the distinctive options to describe a person's relationship with a significant other in the society. It is both physical and moral union that recognize by a society of family. Labour force participation rate of married women is an important issue.
\end{abstract}

Table 2: Percentage Impact of Marital status on Labour Force Participation Rate in Meerut and Unnao

\begin{tabular}{|l|c|c|c|c|c|c|}
\hline \multicolumn{1}{|c|}{ District } & \multicolumn{3}{|c|}{ Meerut } & \multicolumn{2}{c|}{ Unnao } \\
\hline Marital status & $\begin{array}{c}\text { Labour Force } \\
\text { Participation } \\
\text { Rate }\end{array}$ & $\begin{array}{c}\text { Not in Labour } \\
\text { Force } \\
\text { Participation Rate }\end{array}$ & $\begin{array}{c}\text { Total in } \\
(\%)\end{array}$ & $\begin{array}{c}\text { Labour Force } \\
\text { Participation Rate }\end{array}$ & $\begin{array}{c}\text { Not in Labour Force } \\
\text { Participation Rate }\end{array}$ & $\begin{array}{c}\text { Total in } \\
(\%)\end{array}$ \\
\hline Never married & 54.37 & 45.63 & 100.00 & 53.20 & 46.80 & 52.52 \\
\hline $\begin{array}{l}\text { Currently } \\
\text { married }\end{array}$ & 47.40 & 52.60 & 100.00 & 47.48 & 34.75 & 100.00 \\
\hline Widowed & 62.32 & 37.68 & 100.00 & 65.25 & 37.65 & 100.00 \\
\hline $\begin{array}{l}\text { Divorced/sepa } \\
\text { rated }\end{array}$ & 63.51 & 36.49 & 100.00 & 62.35 & 500.00 \\
\hline Total & 52.46 & 47.54 & 100.00 & 50.38 & 49.62 & 100.00 \\
\hline
\end{tabular}

Source- Estimated Field Survey

Table 2 gives the detail of marital status on labour force participation rate in district Meerut. There are 54.37 per cent female who never married and 47.40 per cent currently married, 63.32 per cent widowed and 63.51 per cent are divorced and who are living separated in the family. These females are involved in labour force participation.

\section{Getting Job through Education}

Education is regarded as a key mechanism for the empowerment of female. Education changes their worldview, improves their chances of employment, facilitates their participation in public life, and also influences their fertility. It is generally seen that the chances of employment increase with the increase in education level. This is mostly relevant in case of better paid job or skilled job. However, in informal sector one can participate to work without much education. 


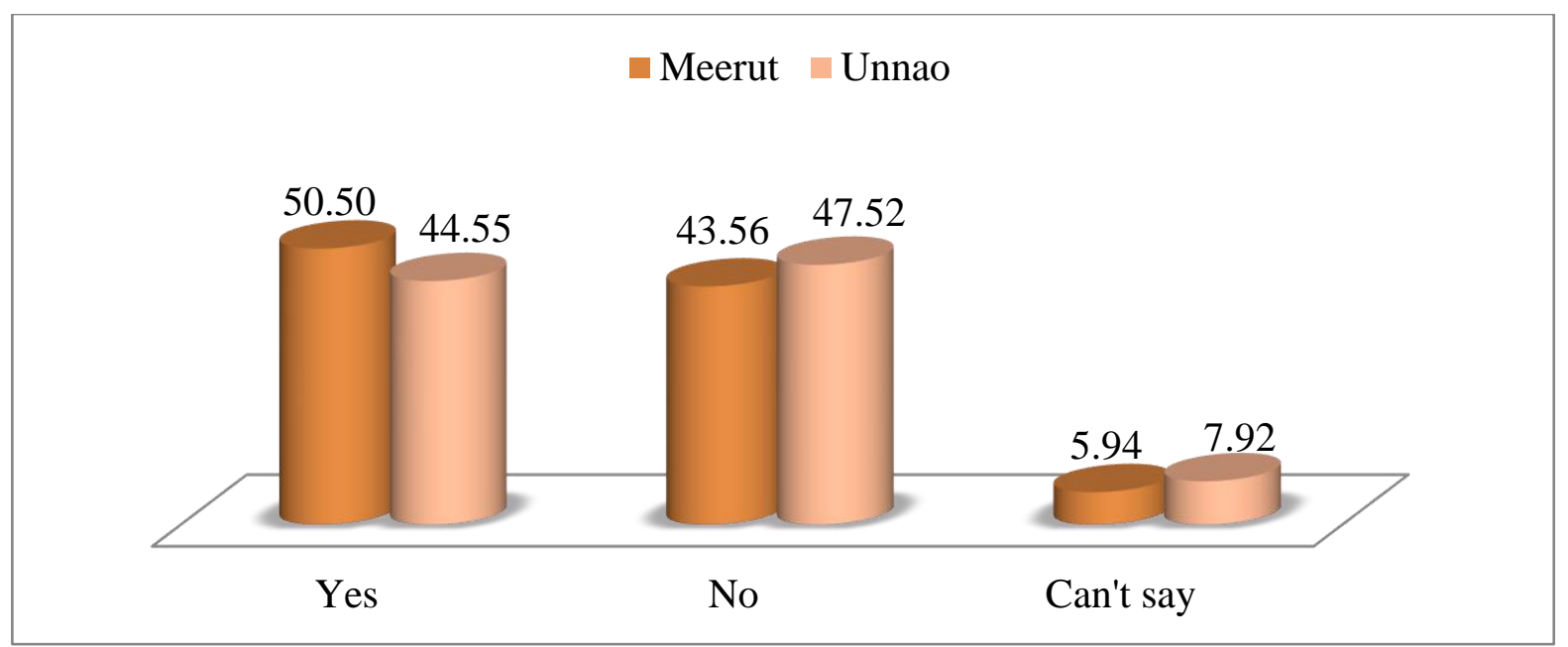

Fig.2: Percentage Wise Females Status of Easily Getting Job through Education

Source- Field Survey

Classification of getting easily job or service throws education in both district Meerut and Unnao. In Meerut 50.50 percent female agree from this perception. In Unnao, it stands for 44.55 per cent. Females reported that through proper education they can get job in the market (figure 2). Females in agree that education is not helping getting easily employment 43.56 per cent and 47.52 per cent in Meerut and Unnao respectively. While, only 5.94 per cent in Meerut and 7.92 per cent in Unnao female's discuses that they cannot say in accurate way. The education institutions are increasing rapidly day by day. Therefore, people are actively participating in education. The awareness is high. Hence, District Meerut has become the hub of education. The percentage of illiteracy in male and female of district Unnao is high as compare to district Meerut.

Female exploitation by employers

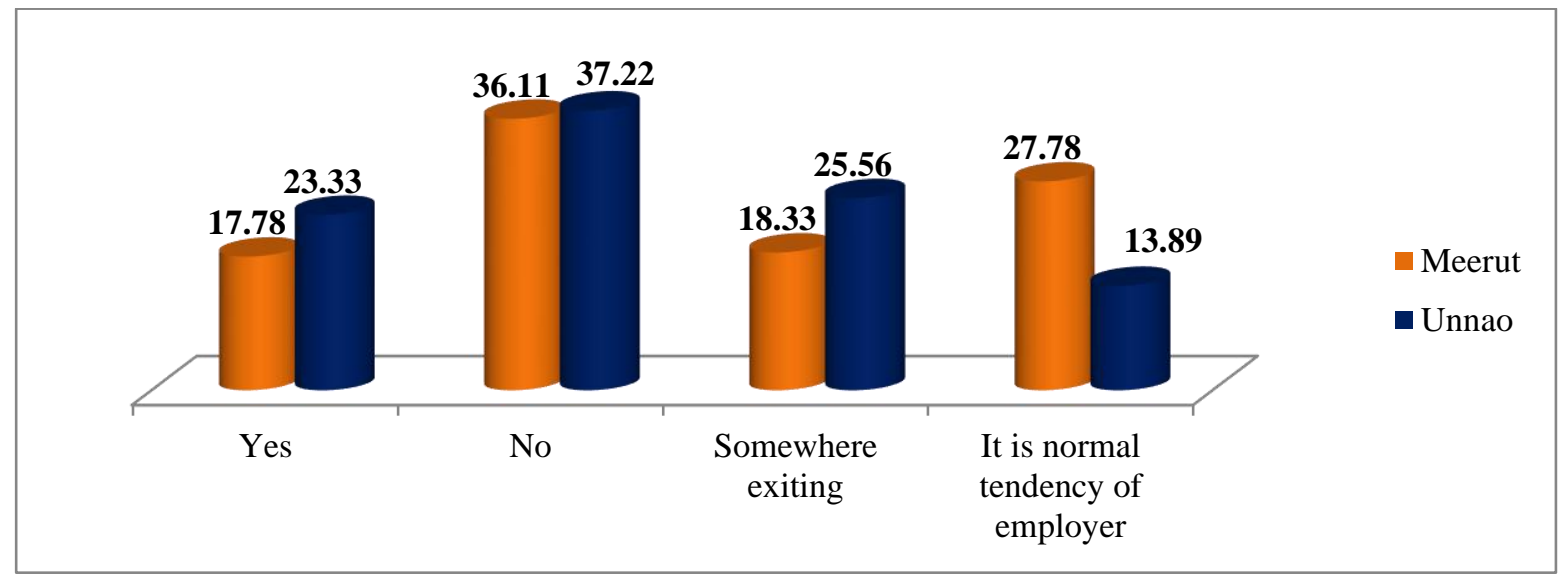

Fig.3: Female exploitation by employers at work place

Source- Estimated Field Survey

Exploitation by their respective employers is much burnt issue in labour market. It is not only found in the unorganized sector but also in the organized sector. Figure 3 gives the detail of exploitation by employers.

Female of Meerut agree that 17.78 per cent are exploited by the work owner and other side 23.33 per cent are suffered in district Unnao in direct or indirect and sometime in both form. While, 36.11 per cent in Meerut and 37.22 per cent in Unnao female do not agree this type of exploitation at work place. In Meerut 27.78 per cent female say that it is normal tendency to exploitation by the employers, but on the other side 13.89 female of Unnao accept this. Women employment is also affected by the nature of the employers. Females encountered many 
challenges at work place. Female's physical harassment took different forms i.e. abusing, scolding, gazing, physical torture, physical touching and sexual exploitation etc. were very common features with working females in the Unorganized sector (Saran, 1990). Frequently, females do not report such happenings to their family members because fear of losing the jobs. They think that these problems are quite common in life. Very few of them reported such events.

\section{Other Factors}

The above analysis concluded that there are many important factors affect female employment in the study area. Labour force participation of females is analyzed under different demographic variables such as age, marital status, education; burden of the family, household's income etc. The level and pattern of female labour force participation depend on employment opportunities. Besides above factors discussed, there are other factors that affect female employment both direct and indirect such as mobility, caste and religion, social factors, thinking of family members of husband side, environment of family background etc.

\section{CONCLUSION}

According to field survey, main problem was found related to employment specially for females because males are going outside for doing work while females have many hindrance to go outside. In Meerut, due to low distance to urban centres from village only find easier to find employment in construction works, driving, vendors etc. Females have a few opportunities for doing work. Females did all kinds of household activities like washing, cooking, cleaning, taking care of children and taking care of the elderly. For working females, their daily time schedule is fixed with household responsibilities. They get up early morning and go to bed late night. Females encountered many challenges at work place in a several form such as 'physical harassment' that took in different forms i.e. abusing, scolding, gazing, physical torture, physical touching and sexual exploitation etc. Besides these causes, females face many other crucial problems like wage discrimination, lowing pay and distress condition. These factors are very significant for low female labour force participation. Due to these socioeconomic and cultural factors, female become a weaker part of the society. Share of female is higher than male in case of unemployed and not reporting to labour force. There is major difference in respect of students between male and female. In both districts, Meerut and Unnao, the numbers of students are high. This is because of many government schemes such as Mid-Day Meal, Serva Siksha
Abhiyan and Right to Education which help to get the more education not only in male but also in case of female. Mostly it examines during survey that people think that boys are helpful in their old ages so they more focus on boys to attain education. After getting education it helps to earn more money and provide them support and facilities. This is the main reason behind this gender difference in education and employment.

\section{REFERENCES}

[1] Kamuruana, G. (2011). Determinants of Female Labour force Participation in Wage Employment: evidence from Kenya (Doctoral dissertation, University of Nairobi, Kenya).

[2] Kaufman, B.E. and J.L. Hotchkiss (2003) The Economics of Labour Markets, 6th edition, Dryden Press, Fort Worth.

[3] Boeri, T., \& Van Ours, J. (2020). The Economics of Imperfect Labor Markets. Princeton University Press.

[4] Gunatilaka, R. (2013). To Work or Not to Work? Factors Folding Women back from Market Work in Sri Lanka. International Labour Organization, ILO DWT for South Asia and Country Office for India.

[5] Breman, Jan. (1985) Of Peasants, Migrants, and Paupers: Rural Labour Circulation and Capitalist Production in West India Delhi: Oxford University Press, 1985. Xxviii, 472 pp.

[6] Chappell, D., \& Di Martino, V. (2006). Violence at work. International Labour Organization.

[7] Phukan.M.1992. 'Status of Labour Women in Tea Gardens of Assam', in S.L.Baruah (ed): Status of Women in Assam. New Delhi: Omsons Publications

[8] NSSO, (2003). Situation Assessment Survey of Farmers. Ministry of Statistics and Planning, Government of India.

[9] Wadhera, K. (1976). The New Bread Winners: A Study on the Situation of Young Working Women. Vishwa Yuvak Kendra.

[10] Sundaram, I. S. (1996). The Plight of Unorganized Workers. Unorganized Women Labourer in India. Discovery New Delhi: Publishing House.

[11] Tripathy, S. N. (1991). Exploitation of Child Labour in Tribal India. Daya Books.

[12] Gangrade, K. D., \& Gathia, J. A. (Eds.). (1983). Women and Child Workers in Unorganised Sector: Nongovernment Organisation's Perspectives. Concept Publishing Company.

[13] Saran, A. B., \& Sandhwar, A. N. (1990). Problems of Women Workers in Unorganized Sectors: Brick Kilns, Quarries, and mines of Bihar and West Bengal. Northern Book Centre. 